\title{
Attitudes of the Community Daily Behavior in Television News As a Mirror of Civic Education (PKn)
}

\author{
Juliati \\ STKIP-PGRI Sukabumi, Indonesia \\ juliatisulaeman1@gmail.com
}

\begin{abstract}
In this era of globalization, we as citizens of the world can experience technological developments where one country with another country can easily find out the strengths and weaknesses of a country along with advances in communication technology which greatly affect citizens. So that from year to year there have been many violations of the law because of the desire to enjoy the pleasures of very high technological advances. This illustrates the problem in which many residents are involved in violations that lead to crime. The solution is with civic education material that must be addressed so that it can adjust to the situation and avoid the negative influence of the very fast development of communication technology. While civic education is considered successful or not, it can be seen from the attitude of people's daily behavior through television news broadcasts, one of which is television news I News RCTI. Then the government can participate in controlling society to make it better (good citizenship). Apart from Civic Skills, Civic Virtues, and Civic Religion, the teaching and learning process must also be improved, including the arrangement of the material along with the teacher's way of teaching through methods, media and models. Since good citizens are not born instantly, but are in a series of interpersonal and intellectual abilities according to the times. The results that can be achieved are that television news must be studied by each individual and then apply the results of the good viewing materials based on that television news for the family, environment and the wider community.
\end{abstract}

Keywords

gldbalization era; television news, attitudes of public behavior, civic education; learning methods

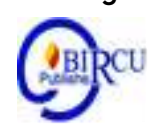

\section{Introduction}

Civic education or civic education (Civics) has long grown and developed in various countries considering that all people long for their young generation to be prepared to become good citizens (good citizenship) so that they can participate properly in accordance with the existing regulations in their environment, in social life and in statehood. This desire is more accurately described as the growing concern or a care in a democratic society to achieve a level of understanding, acceptance of rights and responsibilities among all its citizens along with the maintenance and improvement of constitutional democracy.

We need to recall the term Civic Education with Citizenship Education, which according to Gross and Zeleny (1958: 247) states that Civic is basically concerned with the discussion of governance in the form of democracy in theory and practice, while Citizenship Education is concerned with the involvement and participation of citizens in the people. These two aspects are usually taught in one subject. These two terms in their use of Civics and Citizenship Education are deployed interchangeably to denote a study of governance given in each school. 


\section{Review of Literatures}

\subsection{Globalization Era}

In the current era of globalization, we as citizens of the world can experience the development of science and technology in which countries can find out their strengths and weaknesses through evaluating the impact of various advances in communication technology that affect the behavior of each citizen in various countries. Therefore, there are many people who deal with the law which continues to grow year by year. This indicates that the citizens are involved in many violations, which in turn conflict with good citizenship. Handling the impact of various advances in communication technology that affect behavior is through Civic Education material which must adapt to the conditions of the influence of the development of science and technology so that it can control the community not to be influenced by issues from outside countries including the arrangement of the material and the way teachers are used when teaching using methods, media and models. As stated by Callahan (1990: 338) that good citizens are not born, but are in a series of interpersonal and intellectual skills that are necessary to learn properly and must practice (apply them) to their immediate family environment. This is in line with the opinion of Barber (1992: 245-261) who has made the framework of the civic education model at Rutgers University where he teaches through a combination of schools that requires continuous community service without feeling bored.

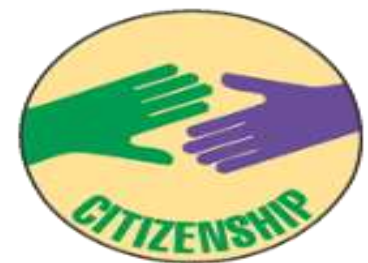

Figure 1. The Symbol of Citizenship

A similar program with several modifications can also be applied to all school levels. Such efforts can assist in renewing our commitment to the national community through dedication to local communities. However, the application of good citizenship is still uneven. Because some have implemented Citizenship Education and some have not. Therefore, the awareness to implement Citizenship Education in the community wherever they belong is still low.

\subsection{Solutions to the Impact of the Globalization Era}

The solution to overcoming the impact of the globalization era is to foster the desire of every citizen to improve themselves through the implementation of Good Citizenship and Civic Virtues and then Civic Religion. This is what the Japanese and Chinese people have shown through their citizenship education, they can do and work better for the progress and peace of their countries. At this time and in the future, why don't we as citizens of a country imitate and change ourselves like what has been implemented in Japan and China. For example: As an expression of the heroic application of patriotism to the nation and state, the government must be able to adjust the material of citizenship education to anticipate the influence of the globalization era by empowering the rapid development of science and communication technology so that there is no more overlapping in the process of cultural development in each country. In fact, few or rare violations were recorded at the local police stations in their respective countries. 


\subsection{Identification of Problems}

The problems that exist in society experience its own dynamics, this must be balanced with Civics material so that it is more contextual and focus to informal matters such as Community Daily Attitudes as a Successful Mirror of Citizenship Education (Civics) around communities where The Good Citizenship has not succeeded, since so many people who still have no sense of tolerance, lying, cheating, and even killing, broadcasted on television news I news RCTI through Special Report. Therefore, solutions and developments from civic education are needed.

Citizenship competence is needed in order to be actively involved in everyday life. In this context, an understanding of the concept of citizenship in the global era is certainly very beneficial for citizens so that they can participate in political and social life at the local, national and global levels, today and in the future. Then the development of a learning model must be achieved in the teaching and learning process. Furthermore, it must be accompanied by the best solution in order to improve citizens towards a better direction. Then the development of this learning model can be applied to analyze the problem that is caused by the various influences of citizens themselves or their environment.

In PPKn National Standard Curriculum for Primary and Secondary Education it is stated that the vision of the PPKn is to realize an educational process that is directed at developing individual capabilities so that they become intelligent, participatory, and responsible citizens who in turn are able to support the development of community, national and state life Smart and virtuous Indonesia (Ginting et al, 2020).

An effort from The National Standards for Civics and Government (Center for Civic Education, 1994) which formulates the main components of civic competence which include civic knowledge, civic skills and civic disposition. Regarding these three components, a statement was found that a number of countries that practiced democracy in the 1990s had conducted research on civic education. Recent studies have found that traditional classes based on civic education can encourage knowledge improvement (Brahm, 2006). Based on this statement, Civics or civic education in this globalization era should be able to adapt to the times through civic skills and civic dispositions.

\section{Research Methods}

\section{Data Collection Techniques}

1. Documentation Study: Watching television, listening to news and reading news in newspapers is the first way to go, because the data is truly reliable. From the news obtained, then pay attention and observe the attitudes of behavior around the environment wherever we are, such as the environment of relatives, the market environment, while shopping, the environment at work, the environment when visiting other big cities. Then it will be seen that there are various behavioral attitudes that appear from each citizen which is reflected in all forms of the problem so that it raises the facts of each individual.

2. Study Literature: At this stage, a search for relevant literature is carried out in books that have been used while in college and search for sources in the city's public library. After that, look for topics to be discussed so that a theme is formed that will be used as discussion. Then, the problem is described to find the causative factors. After the source books have been obtained, the next step is to find solutions that lead to a better life in order to create a more conducive environment (good citizenship), so that we can do activities properly today and for the future with more useful work for ourselves and for others safely (civil attention) which leads to civil religion to fulfill its obligations as a religious community. 


\section{Discussion}

\subsection{Attitudes of Community Daily Behavior in Television News}

\section{a. Attitudes of Community Daily Behavior}

Humans born into the world hypothetically have logical consequences that tend to be more complex. Likewise, a society where the sociological notion of society is not seen as a collection of individuals or as the sum of individuals. According to Ranjabar (2006: 10-11) which states that society is an association in life, because humans live together. In addition, the following is the definition of society according to Mac Iver and Page which states that:

"Society is a system of habits and procedures, of authority and cooperation

between various groups and the classification of behavior control and human freedoms as a whole which we always try to call society. Meanwhile, society is a fabric of social relations that is always changing."

Society is not just a collection of a number of individuals, but more than that. Society is a system that is formed by associations between individuals in it and represents a certain reality that has its own characteristics from a group of people who think then they will act in a different and isolated way so that everything is left behind like human activities in general (Durkheim, 1895). Society is defined as people in general, living together in communities, whereas language is a means of communication to express our feelings, thoughts, ideas, etc (Ramlan, 2018).

Attitudes of Public Behavior in Television News according to experts, such as statements from Theory of Reason Action and Theory of Planned Behavior about how attitudes affect behavior. The following is a brief description of these theories:

\section{1). Theory of Reason Action}

Fishben and Ajzen (in Sarwono and Meinarno, 2009) said that the decision to carry out certain behaviors is the result of a rational process. Then to find out how the attitude and behavior relates where the object of the attitude in question is none other than the behavior itself, several behavioral choices must be considered, consequences and results are assessed, then a decision is made to do or not do something (intention). The decisions taken show or are reflected in the intention to do or not to do the behavior.

\section{2). Theory of Planned Behavior}

Ajzen (in Sarwono and Meinarno, 2009) said that the relationship between attitude and behavior is in a theory of reasoned behavior, and it does not explain behavior that others cannot fully control, even though they have a positive attitude towards the intended behavior. For example, a student who graduated from high school wants to continue his education to the college he wants. He has a positive (good) attitude towards the college and the people around him, such as parents, friends, teachers, and siblings who support his desire. However, there are many factors that contribute to college admission, such as the opportunity to pass the college entrance exam and the financial resources required for this behavior.

Overall, all of them affect the intention or will, namely one's intention to do something. Intention is a major predictor of behavior. This means that intention is a motivational factor that has a very strong influence on behavior so that people can expect other people to do or not do something based on their intentions. 


\section{3). Attitude-to-Behavior Process Model}

The relationship between behaviors is spontaneous. Fazio (in Sarwono and Meinarno, 2009) explains things like when we are faced with events or events that take place quickly, such as:

a. Attitude towards Behavior

Spontaneously, the attitude that exists within us will direct the behavior and events that we experience by showing a certain attitude towards the object of the attitude we face. The attitude that is formed will affect our perception of the object of attitude. At the same time, our knowledge of social norms whereby what is appropriate or inappropriate behavior by a person regarding an event can influence perceptions of the event. Attitudes and knowledge that are contained in our memories, influence perception and in turn influence our behavior.

\section{b. Society}

Groups in society are not just a group of individuals. More than that, society is a system formed by associations among individuals in it and represents a particular reality which has its own characteristics. Community groups that are formed will think, feel and act differently from those who are isolated (Durkheim, 1895).

\section{c. Family Environment}

Family is a place where a person lives in his group. In addition, according to the opinion of Horton and Hunt (1993: 267), family is a system of norms and procedures that are accepted for completing a number of important tasks. And a family might be:

1). A group that has a common ancestor;

2). A kinship group united by blood or marriage

3). Married couples with or without children;

4). Unmarried couples who have children;

5). One person with several children.

Members of a commune may identify themselves as family, but are generally unable to live in a house in an area designated as a single family residence.

Meanwhile, the family environment has a different meaning. The family environment is a rather large group of families where the child is a joint responsibility of the whole family so that the child develops a relationship with his aunt that is almost the same as his mother. Then, each child is surrounded by several adults who act as parents. This type of family creates a more collective personality because each child has more or less the same socialization experience. Such a family protects each individual from the threat of an unfortunate fate if his mother dies. The replacement is already there. Because a family that is related by blood keeps children away from individualistic traits and protects them from loneliness or abandoned (Horton and Hunt, 1993: 270).

\section{d. Attitudes of Community Daily Behavior Can Be Seen on Television News}

Society is not just a collection of individuals. More than that, society is a system formed by associations between individuals in it and represents a certain reality that represents its own characteristics in the formed community groups who think, feel, and act differently from those who are isolated (Durkheim, 1895) and no one is alone (Sondheim, 1986).

We also asked about the sections of society and how they carry out their functions. Because social science is studied through its main institutions and the role it plays in solving problems and helping community performance. Problems in social life with their 
subject matter must be met and all human needs, both the most basic and in general, will involve the structure of government institutions for a country to present the most basic things in social functions, problems in life and institutions (Plummer, 2011: 42-43). Here is a table of the problems of life and their subject matter in society:

Table 1. Life Problems \& Main Problems

\begin{tabular}{|l|l|}
\multicolumn{1}{|c|}{$\begin{array}{c}\text { Problems in social life } \\
\text { with their subject matter }\end{array}$} & \multicolumn{1}{c|}{ Structure, institutions and practices } \\
\hline $\begin{array}{l}\text { 1. Obtaining the basic necessities of food, } \\
\text { shelter }\end{array}$ & $\begin{array}{l}\text { 1. Economy (includes work activities and } \\
\text { consumption) }\end{array}$ \\
\hline 2. Organize - Reaching goals & 2. Politic \\
\hline 3. Take care of everything, stay in order & 3. Law and Socialization \\
\hline 4. Producing & 4. Family, family ties, intimate relationships \\
\hline 5. Build good relationships & 5. Civil life, citizenship, welfare \\
\hline 6. Develop communication & 6. Language and Media \\
\hline 7. Study, develop, science and knowledge & 7. Science and education \\
\hline 8. Cultivating the other spiritual side of life & 8. Religion \\
\hline
\end{tabular}

In order to respond to society such as the human factor referred to in the table above, it is certain that there are needs that must be realized and fulfilled, both general and personal needs. Therefore, humans and their groups work hand in hand to meet their needs, especially those of a general nature such as obtaining food, shelter, to spiritual needs that are spiritual in nature for human life.

Meanwhile, the attitude of the daily behavior of the surrounding community is a system formed by associations between individuals and represents a certain reality which has its own characteristics where the attitude will spontaneously lead to and influence our perceptual behavior about the object of that attitude. At the same time, it will determine social norms regarding what behavior is appropriate or inappropriate for someone to do so that it affects the perceptual memory of our future attitudes and knowledge.

\section{b. Television News Broadcast}

Television is a communication technology tool that provides various information to the public about what has happened in the community with various events that can be justified for clarity. The information technology that is even more advanced today is the internet, through Google, the presence of news broadcasts comes faster than television news. Television news broadcasts air based on a predetermined time. The broadcast reports about events that occurred in the community where the most content is about news of violations, extortion and murder which is increasing in number. Even though Indonesian schools have been given Civics lessons, as for abroad and in various countries civic education has been implemented for all school levels, starting from children (TK) to higher education.

\section{1) As a Reflection of Civic Education (Civics)}

The definition of a mirror according to the Indonesian dictionary from the language center of the Ministry of National Education is that one of the faces is given a polish so that it can show something of the truth. The meaning of mirror in Civic Education (Civics) means something that can be used as an example for learning as a vision of the mission of Civic Education (Civics), which is to make citizens live better lives through their daily behavior in society. As stated earlier that the attitude of people's daily behavior, spontaneously, the object of their attitude will lead to and influence the behavior of other 
human perceptions. And at the same time, it will determine social norms regarding what behavior is appropriate or inappropriate for someone to do so that it affects the perceptual memory of the events of our attitude and our next knowledge.

The other side of society is currently cooperating in various fields such as cooperation in the trade sector such as the Asian Economic Community (MEA) program. However, it turns out that there are negative sides and there are also positives like there are (accessed on the internet, Tuesday 29-12-2015).

Regarding to citizenship education, there are several opinions and research on the competence of citizenship education which are still not evenly disseminated, even seeming very lacking. This can happen because of the influence of the development of communication technology in the era of globalization so that there are still many ideas that have not been conveyed. Citizenship education must be forgotten because it is complacent with worldly pleasures where information about tourist and recreation spots can be accessed easily and can indulge one's desires.

Apart from the function of citizen participation regarding the application of rights and obligations when electing leaders in general elections. Duties, functions and roles as family members will be even better if they can base this definition of citizenship education competence with these three essential components. Margaret Stimman Branson describes this in her book effective civic education, in order to have citizenship competence one must have civic knowledge, civic skills and civic disposition. (Branson, 1998). Therefore, let's take a look at the following image below:

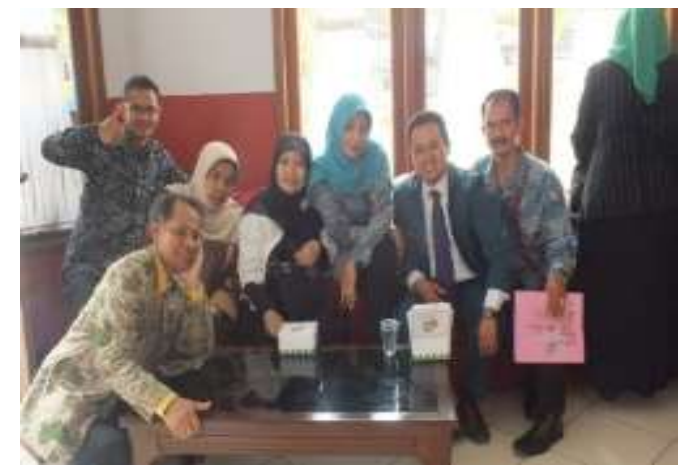

Figure 2. Various Attitudes of Community Behavior

Based on the image above, we can see several different poses, especially those related to people's attitudes in carrying out their activities. There is nothing in common in the poses they do. In addition, attitudes towards the family environment where someone lives to meet their needs are still not in harmony between material character and citizenship. This is like a new family when they promise to have a family in front of the headman, but the implementation is still not appropriate, even contrary to the promised reality, as happened in the list below:

1. There are still injustices in carrying out daily activities towards relatives and their family environment.

2. There is still an inappropriate attitude in the family environment and towards his relatives, even after committing the inappropriate act, his attitude does not show the slightest sense of sin;

3. Violence happened that you did not expect, whether it was done openly or privately.

In accordance with the above family problems that still do not reflect the ideal family, such as incompatibility with the oath of marriage in front of the headman, the general role of the family will have a negative impact on the social development of 
children both to their relatives and their environment, even more so negatively on the community. This refers to the opinion of Gerungan (2010: 195) that:

"Therefore, the family is the first social group in human life. Where humans learn and express themselves as social being in terms of interaction with their groups. Everything that has been described regarding group interactions also applies to family group interactions which are the primary groups, including the formation of social norms, norms interaction forming frames of reference, behaviorism and others. Social interaction in the family is based on sympathy, first of all, learning to pay attention to the desires of others, learning to cooperate, and helping out. In other words, the first lesson is learning to play a role as a social being who has certain norms and skills in his interactions with other people. "

Referring to his opinion above, there are forms of behavioral attitudes in activities towards the community and family environment which can be explained as follows:

\section{2) Behavior Model}

Basically, the form of behavior can be observed through attitudes and actions. However, this does not mean that the form of the behavior can only be seen from the attitude and actions. Behavior can also be potential, namely in the form of knowledge, motivation and perception. Bloom, et. al. (1956) differentiated the behavior into 3 kinds of core behavior, namely "Coqnitive, Affective and Psychomotor. This opinion is defined as behavior which includes: Knowledge, Attitudes and Actions, while Ki Hajar Dewantara calls it Cipta, Rasa, Karsa or Peri Akal, Peri rasa, and Peri Tindakan. The form of behavior seen from the point of view of response to stimulus, behavior can be divided into two, namely:

a. Closed Behavior

Closed behavior is a person's response to a stimulus in a covert or closed form. The response or reaction to this stimulus is still limited to attention, perception, knowledge or awareness, and the attitude that occurs cannot be clearly observed by others.

b. Open Behavior

Open behavior is a person's response to a stimulus in the form of real or open action. The response to the stimulus is clear in the form of action or practice.

\section{3) Behavior Formation Process}

The process of forming behavior is influenced by several factors originating from within the individual himself, these factors includes Perception, Motivation and Emotions. It can be interpreted that a person's behavior arises due to emotions resulting from the influence of his environment or is innate behavior. So that emotions can lead to conflict between the environment and himself and if the conflict cannot be managed properly, it can become an act of aggression. Then will lead to a Violence and eventually become an act of crime against the environment.

\section{4) The Role of the Government for the Development of Civic Education (PKn)}

All attributes of the form of behavior, as previously discussed, from the point of view of response to stimulus, it is necessary to develop it through the role of government and non-government institutions, including the mass media (Cogan, 1999). Furthermore, Winataputra and Budimansyah, (2007) state that new mass media need to contribute in creating the growth of new awareness about the world that is shared.

The description above shows that in this era of globalization, building civic competence is very important and urgent to do as stated by Robertson (1990) that 
globalization will become an intellectual "Play Zone" which is a place to express interest, social, theoretical residuals, interpretive indulgence, or display of idealistic world preferences.

If indeed the attitude of the community's daily behavior and the family environment is not good, such as the number of cases that lead to crime, then Citizenship Education cannot be said to be successful and the government and its staff must be able to overcome it so that the community, family environment and country are safe. Because there are many crimes, or cases of violence in the household, such as husbands tricking their wives, or vice versa, or parents deceiving children. These cases occur and everything is as commonplace. If we think about whether this has become homo hominid lupus in these countries?

\section{a. Research on Civic Education}

In particular, Research on Civic Education suggests several findings regarding attitudes of public behavior in television news that can produce Good Citizenship. As stated by Brahm in the bibliography of Post-graduated UPI Bandung students (2013), namely:

1) Citizenship knowledge can help citizens understand their interests as individuals and members of a group

2) The participation program must have consistency in view of issues that can transcend time

3) Specific knowledge related to political institutional processes, giving individuals a better understanding of political events and integrating new information into existing frameworks

4) Knowledge of citizenship in general can change views on specific public issues

5) Citizens with better citizenship knowledge will be less alienated from public life

6) Better citizenship knowledge can support democratic values

7) Better citizenship knowledge will increase participation in political processes.

The prospect of developing the potential for citizenship in the global era is encouraging with the emergence of concern from many countries for civic education. This can be seen based on the research using Ethnographic Delphi Future Research (EFDR) involving 182 countries (Safria, 2013) which recommends the need for a description of the development system of the civic education (Civics) model which is better known as multidimensional citizenship conceptually. Because civic education (Civics) still has five important attributes that might differ in each country according to the political system of each country, namely:

1) A sense of identity

2) The enjoyment of certain right

3) The fulfillment of corresponding obligations

4) A. Degree of interest and involvement in public affairs and

5) An Acceptance of basic societal culture.

Conceptually, a citizen has five important attributes, namely self-identity, freedom to enjoy of certain rights, fulfillment of obligations, level of interest and involvement in public affairs. So the ownership of basic values in society such as the level of interest, involvement in public affairs is when socializing to carry out life activities. 

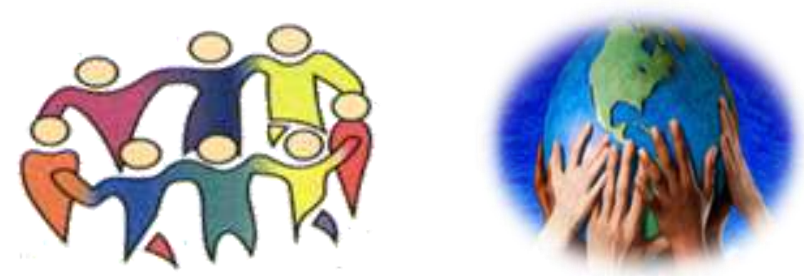

Figure 3. Logo of Global Citizens Hand in Hand to Face Community Diseases

Figure 3 above shows that the world's citizens work together to protect the world from all forms of threats and disturbances in various fields and improve world citizens who still have bad behavior so that they become even better. In this case, the Minister of Women's Empowerment and Child Protection of Indonesia, as a government staff, actively monitors and handles various cases of sexual abuse against children and various cases of violence against members of the family environment on an ongoing basis.

b. Schoeman (2006) in the Bibliography of Post-UPI Bandung Students (2013)

This study discusses teachers' perceptions of democratic education, a type of civic education in South Africa, which proves that democratic education in the classroom can make students become good citizenship. Every country that wants to advance or continue to exist in the global arena of course expects quality and responsible participation from its citizens both in political life and in social life at the local, national, and international (global) level. Such participation can only be done if the citizens have sufficient citizenship competence. The higher the citizenship competence of a citizen, the more advanced the country will be.

Another example in accordance with the information above is from University of Muhammadiyah Prof. Dr. Hamka (UHAMKA) who has been appointed as an ambassador for the Gender and Child Protection Studies Center (PSPGA) by the Minister of Women Empowerment and Child Protection of the Republic of Indonesia in order to socialize good citizenship with the theme "Stop Violence Against Women and Children". This campaign was carried out by distributing pamphlets and roses to people crossing the highway in the capital Jakarta in April 2016 as well as to commemorate KARTINI day. In addition, there is also a 2016 International Seminar Proceding with the theme Gender Perspective Development of Multiliterate Development in the ASEAN Economic Community Era for the collaboration between UPI Bandung, the UHAMKA Gender and Child Protection Study Center (PSGPA), the Ministry of Women's Empowerment and Child Protection of the Republic of Indonesia. University Sains Malaysia (USM), and USAID PRIORITAS from Korea.

This activity was held because there were so many cases that happened to women and children in the community. Therefore, universities become strategic partners of local governments to make effective formulations as solutions for the environment in which they are located. In addition, one application of the planning context for teaching and learning from UUSP no. 20 of 2003 article 39 paragraph (2) which reads that Educators are professionals who are tasked with planning and implementing the learning process and assessing learning outcomes and Article 40 paragraph (2) which reads that Educators and educational staff are obliged to:

a. Creating an educational atmosphere that is meaningful, fun, creative, dynamic and dialogical;

b. Having a professional commitment to improving the quality of education; 
c. Setting an example and maintain the good name of professional institutions and positions in accordance with the beliefs given.

Based on what is stated in the law and the articles in it, it is hoped that universities will not be tired of monitoring and covering various cases in society because this is part of the application of Civics regarding daily behavior in society as a reflection of success. Citizenship education in Indonesia is one of the fields of study that refers to the Pancasila Ideology and the Preamble to the 1945 Constitution and all the articles in it. However, it seems that Civics in Indonesia are still not successful because of the many cases that occur in society from year to year. The legal problems faced by society, both criminal and civil, are centered on the District Court and deal with the Religious Courts which handle cases such as heirs and divorce cases. In addition, various criminal acts such as fraud, extortion and murder continue to be broadcast on television news broadcasts through I News RCTI and Sergap criminal news, considering that Indonesia is a country that adheres to Pancasila which consists of five principles, namely: 1. Almighty God 2. Fair and civilized humanity 3. Indonesian unity 4. Community led by wisdom in deliberation and representation 5 . Social justice for all Indonesian people.

Therefore, the Government as the organizer of the leadership must be able to ensure that the people have the right to legal protection of article 27 paragraph 1. Moreover, the Government Apparatus as the organizer through their leadership must be fair and trustworthy in carrying out their leadership duties in accordance with the word of Allah SWT. (Q: S: Annisa, 4:58). But basically this is not in accordance with the reality, the community has carried out many violations and courts both state and religion are flooded with orders to resolve cases that occur in the community, especially Civics in middle schools (SMA and SMP) are given only one session per week. In addition, Civics are now not on the national final exam. Therefore, how can you create the good citizens without the role of Civics? For this reason, according to Solihat (2014) states that:

"Because there is no conformity between the nation's philosophy and regulations in Indonesia which allow for the ratification of international treaties in which Indonesia is a rule of law. Because Indonesia has a judicial review such as: Case examination no.33 / PUU-XI / 2011. 38 of 2008 and in international law known as ratification in the context of the Indonesian constitution in article 1 letter b of Law no. 24 of 2000 is about international treaties which explain that the ratification of legal acts to improve oneself in an agreement in the form of ratification (accretion) and acceptance (acceptance) and approval (approval). "

In order to fulfill the international obligations as an international community in the Preamble of the 1945 Constitution, the Indonesian government is obliged to protect the entire Indonesian nation and participate in implementing world order based on independence, eternal peace and social justice. In this case, it is very clear that the Government and all forms of community activities must act in accordance with the existing regulations with the objectives and set forth in the preamble to the 1945 Constitution.

\section{Conclusion}

Nowadays, Civic education (Civics) should be applied at all levels of education, not just as knowledge or merely a theory. Likewise, the community must also receive regular socialization about Civics material in its application when carrying out daily life in the environment where they are in a sustainable manner. Then, who will protect and love their homeland if we as citizens of one country and as citizens of the modern world do not participate in political and governmental activities. Because we are citizens who have 
legality in their social status as part of the political community and citizens who promote public services from bad rulers. Therefore, as modern citizens we must exercise direct supervision of the sovereignty of the state and be consistent with the state constitution.

Therefore, all citizens of the world should realize that civic education is very important to maintain the continuity of constitutional democracy, since the ethos of democracy is not inherited. Each generation is a new society that must acquire knowledge, learn morality and develop character or character in a public or private context that is in line with constitutional democracy. This mental attitude must be nurtured through speech and teaching and by the power of representation. Democracy is not a machine that will function by itself, but must be consciously reproduced from one generation to the next as well.

For this reason, students at all levels and types of school must be prepared to become citizens who have multidimensional intelligence. Then, local government officials in their respective circles must be active and intervene to socialize it, for example; through banners in his office. So the existence of civic education (PKn) will be even better for its daily application so that news broadcasts on television do not preach too much about crimes, such as: fraud, extortion, and murder, because the Indonesian state has the Pancasila philosophy. Likewise, with other countries in the world that have their own regulations in running their wheels of government, especially for their people at every level of education who learn civic education (PKn).

\section{References}

Afidatussolihat. 2014. Jurnal Cita Hukum volume II no.1 Juni 2014. UIN Syarif Hidayatullah Jakarta

Barber, Benyamin. 1992. Anotasi Bibliografi Tahun 2008. UPI Bandung: Sekolah Pasca Sarjana S3 Pendidikan Kewarganegaraan

Bloom, Benyamin. 1956. Bloom's Taxsonomy Learning in Action.

Brahm, Eric .2006, Biblografi Mahasiswa PKn S3 Pasca UPI Bandung Tahun 2013. Bandung

Branson, Margaret S. 1999. Belajar Civic Education dari Amerika. Lembaga Kajian Islam dan Sosial (LKS) dan The Asia Foundation (TAF);

Callahan, William T. and Banaszak, Ronald A. 1990. Citizenship for the twenty-first century

Durkheim, Emile. 1895. Sociology The Basics. Jakarta: PT Raja Grafindo Persada

Gerungan, W.A. 2010. Psikologi Social. Bandung: PT Rifika Aditama.

Ginting, S.J.B., et al. (2020). The Effectiveness of Citizenship Education (PPKn) Module on Environmental Love Material by Using Example Non Example Learning Model. Budapest International Research and Critics in Linguistics and Education (BirLE) Journal. P. 647-661.

Gross dan Zeleny 1958) PKn dan Masyarakat Kultural, PKn. Bandung: Pasca Sarjana UPI Bandung

Horton, Paul B. and Hunt, Chester L. 1993. Sosiologi. Bandung: Erlangga

Kamus Besar Bahasa Indonesia. 2001. KBBI Edisi Departeman Pendidikan Nasional. Jakarta: Balai Pustaka

Kartono, Kartini. 2010. Metode Penelitian. Bandung: Alumni

Plummer, Ken. 2011. Sosiology the Basic. Jakarta: PT Raja Grafindo Persada 
Ramlan. (2018). Some Steps for Language Maintenance in The Society and Individual. Budapest International Research and Critics Institute-Journal (BIRCI-Journal). P. 6271.

Ranjabar, Yacobus. 2006. Sistim Social Budaya Indonesia Suatu Pengantar. Indonesia: Ghalia Indonesia

Rozi, A., \& Sunarsi, D. 2020. The Influence of Motivation and Work Experience on Employee Performance at PT. Yamaha Saka Motor in South Tangerang. Jurnal Office, 5(2), 65-74.

Sarwono dan Winarno 2009. Teori Sikap dan Perilaku Menurut Para Ahli. Di akses dalam Internet, Link: http://www.Phikologiku.Com/

Sunarsi, D. (2017). Pengaruh Disiplin, Motivasi, Dan Kompetensi Terhadap Prestasi Belajar (Studi Kasus Pada Mahasiswa Universitas Pamulang, Tangerang Selatan Tahun Akademik 2016-2017). Jurnal Mandiri: Ilmu Pengetahuan, Seni, Dan Teknologi, 1(2), 207-226.

Supriyadi, D., Syafitri, L. N. H., Widodo, S. F. A., Wahidi, R., Arinta, Y. N., Nabhan, F., ... \& Cahyono, Y. (2020). Innovation And Authentic Leadership Of Islamic University Lectures In Faculty Pharmacy Faculty: What Is The Role Of Psychological Capital?. Systematic Reviews in Pharmacy, 11(8), 383-393.

Winataputra dan Budimansyah. 2007. Civic Education Kontek Landasan Bahan Ajar dan Kultur Kelas Pasca Sarjana UPI Bandung. Bandung

Yuangga, K. D., Jasmani, J., \& Sunarsi, D. (2017). The Influence of Technology Determinism and Technology Literacy on Student Learning Outcomes (On MA Daarul Hikmah Pamulang). PINISI Discretion Review, 1(1), 23-30. 